\title{
A COMPUTER PROGRAM FOR CONVERTING RECTANGULAR COORDINATES TO LATITUDE-LONGITUDE COORDINATES
}

By A.T. Rutledge

U.S. GEOLOGICAL SURVEY

Water-Resources Investigations Report 89-4070

Prepared in cooperation with the

NORTHWEST FLORIDA WATER MANAGEMENT DISTRICT

ST. JOHNS RIVER WATER MANAGEMENT DISTRICT

SOUTH FLORIDA WATER MANAGEMENT DISTRICT

SOUTHWEST FLORIDA WATER MANAGEMENT DISTRICT

SUWANNEE RIVER WATER MANAGEMENT DISTRICT

Tallahassee, Florida 


\section{DEPARTMENT OF THE INTERIOR}

MANUEL LUJAN, JR., Secretary

\section{U.S. GEOLOGICAL SURVEY}

Dallas L. Peck, Director

For additional information write to:

\section{District Chief}

U.S. Geological Survey

Suite 3015

227 North Bronough Street

Tallahassee, Florida 32301
Copies of this report can

be purchased from:

U.S. Geological Survey

Books and Open-File Reports

Federal Center, Building 810

Box 25425

Denver, Colorado 80225 


\section{CONTENTS}

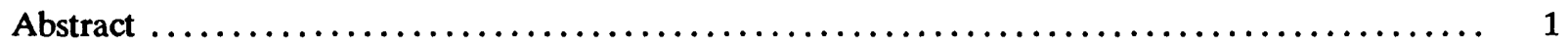

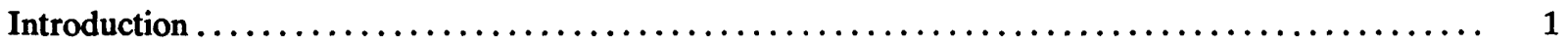

Conversion of rectangular coordinates to latitude-longitude coordinates $\ldots \ldots \ldots \ldots \ldots \ldots \ldots \ldots \ldots, 1$

User procedure for computer program application $\ldots \ldots \ldots \ldots \ldots \ldots \ldots \ldots \ldots \ldots \ldots \ldots \ldots \ldots \ldots, 2$

Selected reference $\ldots \ldots \ldots \ldots \ldots \ldots \ldots \ldots \ldots \ldots \ldots \ldots \ldots \ldots \ldots \ldots \ldots \ldots \ldots \ldots \ldots \ldots \ldots \ldots \ldots, 8$

Appendix--Computer program listing $\ldots \ldots \ldots \ldots \ldots \ldots \ldots \ldots \ldots \ldots \ldots \ldots \ldots \ldots \ldots \ldots \ldots$

\section{ILLUSTRATIONS}

Figures 1-5. Diagrams showing:

1. Simplified grid conversion based on translation between two rectangular coordinate systems ..... 3

2. Adjustments necessary for calculating new grid column number $\ldots \ldots \ldots \ldots \ldots \ldots \ldots \ldots \ldots, 4$

3. Adjustments necessary for calculating new grid row number $\ldots \ldots \ldots \ldots \ldots \ldots \ldots \ldots \ldots \ldots$

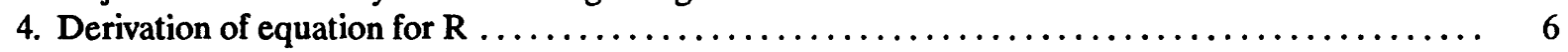

5. Flow chart of procedures used by the program $\ldots \ldots \ldots \ldots \ldots \ldots \ldots \ldots \ldots \ldots \ldots \ldots \ldots \ldots \ldots$ 


\title{
A COMPUTER PROGRAM FOR CONVERTING RECTANGULAR COORDINATES TO LATITUDE-LONGITUDE COORDINATES
}

\author{
By A.T. Rutledge
}

\begin{abstract}
A Fortran-77 computer program was developed for converting the coordinates of any rectangular grid on a map to coordinates on a grid that is parallel to lines of equal latitude and longitude. Using this program in conjunction with ground-water flow models, the user can extract data and results from models with varying grid orientations and place these data into a grid structure that is oriented parallel to lines of equal latitude and longitude. All cells in the rectangular grid must have equal dimensions, and all cells in the latitude-longitude grid must measure 1 minute by 1 minute. This program is applicable if the map used shows lines of equal latitude as arcs and lines of equal longitude as straight lines and assumes that the Earth's surface can be approximated as a sphere.
\end{abstract}

The program user enters the row number, column number, and latitude and longitude of the midpoint of the cell for three test cells on the rectangular grid. The latitude and longitude of boundaries of the rectangular grid also are entered. By solving sets of simultaneous linear equations, the program calculates coefficients that are used for making the conversions.

As an option in the program, the user may build a ground-water model data file based on a grid that is parallel to lines of equal latitude and longitude. The program reads a data file based on the rectangular coordinates and automatically forms the new data file.

\section{INTRODUCTION}

Finite-difference grids that are used in conjunction with ground-water flow models commonly are not oriented along latitude or longitude lines but are oriented in a way that enables the modeler to show predominant flow paths along one axis of the grid. Extracting data or results from a model for other related uses, including modeling at a detailed level, may be complicated because the model grid does not coincide with a universal land coordinate system.

The Fortran-77 computer program described here allows the user to transfer data from a rectangular grid that can be oriented in any direction on a map (referred to as the old grid) to a grid that is oriented such that it consists of lines of equal latitude and longitude (referred to as the new grid). Cells, which are the elemental units of model grids defined by two coordinates, must be rectangles of uniform dimensions on the old grid and must be areas measuring 1 minute of latitude by 1 minute of longitude on the new grid. New grid coordinates are assigned such that the origin is at the northwest corner and row number increases to the south, whereas column number increases to the east. The size of cells on the old grid may be different from that of the new grid, but the results may not be useful if old grid cells are substantially smaller than new grid cells because the coordinates of several old grid cells might translate to the coordinates of a single cell in the new grid.

\section{CONVERSION OF RECTANGULAR COORDINATES TO LATITUDE-LONGITUDE COORDINATES}

The simplified conversion of old grid coordinates to new grid coordinates is shown in figure 1. In this example, both grids are rectangular. Simple mathematical relations can be derived to calculate the coordinates on the new grid at a location that is defined by coordinates on the old grid. This is shown as equations (1) and (2) in figure 1. The new row number (eq. 1) is calculated through the use of a first-order polynomial in two variables: the old row number and the old column number. The new column number (eq. 2) is determined similarly. These two equations have their coefficients (X1-X6) determined by the solution of three simultaneous first-order equations written for three test cells. New grid test cells are chosen such that their midpoints coincide 
as closely as possible with the midpoints of old grid cells. After the six coefficients of equations (1) and (2) have been determined, the equations will give new grid coordinates of the midpoints of any old grid cell. Ground-water flow-model variables, such as transmissivity, assigned to an old grid cell then may be assigned to that cell's corresponding cell on the new grid.

The intended use of this program is for converting coordinates on the old grid to coordinates on the new grid, where the new grid is made up of lines that are parallel to lines of equal latitude and equal longitude and where lines of equal latitude are arcs and lines of equal longitude are straight lines (as is the case on a map that is a Lambert conformal conic projection). Because the new grid coordinate system therefore is radial, instead of rectangular, adjustments in the simplified grid conversion in figure 1 are necessary.

The necessary adjustments to the previously described approach for determining a new grid column number are shown in figure 2 . The diagram on the left portrays two equal east-west displacements at two different latitudes. Because the lines of equal longitude converge, the equal displacements cause the two new column numbers to differ. The diagram on the right shows the derivation of an expression for the adjustment necessary, and the revised equation for $J_{\text {new }}$ is shown (eq. 3). It is assumed here that the Earth's surface can be approximated as a sphere. Before equation 3 is solved, an expression for approximate latitude must be solved. The error associated with this calculation (eq. 4) is relatively small and considered insignificant because approximate latitude is used only for determining cosine of latitude, and errors transferred by way of the cosine function are small.

The need for an adjustment in the equation for a new grid row number is illustrated by the left diagram in figure 3. The previous equations (fig. 1) would be inadequate because they do not allow for the apparent northward curvature of the arcs of equal latitude. The adjustment for this curvature is represented by $\Delta I$ in equation 5 . The adjustment is formulated to be zero at the western edge of the new grid and to increase eastward. The derivation of the expression for this adjustment (eq. 6) is shown on the right diagram in figure 3. An expression for the $R$ term is shown in figure 4 (eq. 7).

The procedures used by the program are illustrated in figure 5. User input consists of latitude-longitude coordinates of the boundaries of the new grid and of three test cells. Equation 7 is executed first, and $R$, a characteristic of the new grid, is determined. By use of location data pertaining to the three test cells, the program solves for the coefficients of equations 4,3 , and 5 , in that order. On the basis of the same equations, having their coefficients as known values, the program then converts old grid coordinates to new grid coordinates.

\section{USER PROCEDURE FOR COMPUTER PROGRAM APPLICATION}

To execute this program, the user needs the latitude and longitude of the northwest and the southeast corners of the new grid, the coordinates of three test cells on the old grid, and the latitude and longitude of the midpoint of these cells. The program prompts user input. The test cells should be located as far from each other as possible and, preferably, should be cells that represent actively modeled areas. Any two test cells should not be located at the same approximate latitude or the same approximate longitude. After the program calculates conversion coefficients, the user may test the program by requesting new-grid coordinates of the test cells previously given. The calculated coordinates of these should be equal to the values given during input. When the user is satisfied that data have been entered correctly, the program can be tested further by requesting the new grid coordinates of cells not previously given.

The user may exit the "cell testing" procedure and then choose to either terminate the program execution or opt to build a data file in new grid coordinates. If the second option is chosen, a file named "OLDDATA" must be in the directory. This is a data file configured on the old grid format. It can be transmissivity, leakance, head, or any other model input data. The program prompts the user to enter the dimensions of the old grid (number of rows, number of columns) and then creates a data file named "NEWDATA," which is configured on latitude-longitude 


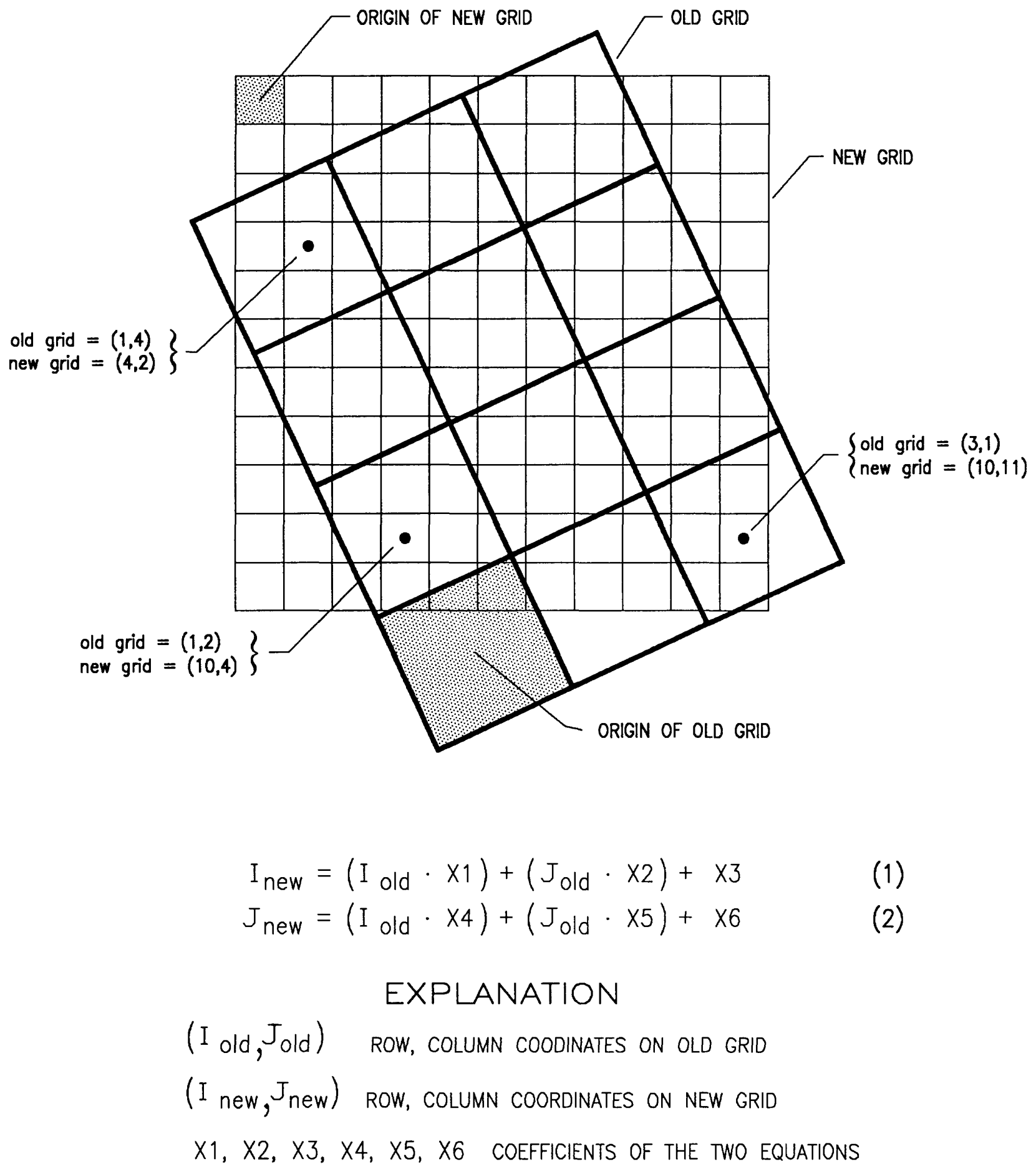

Figure 1.--Simplified grid conversion based on translation between two rectangular coordinate systems. 


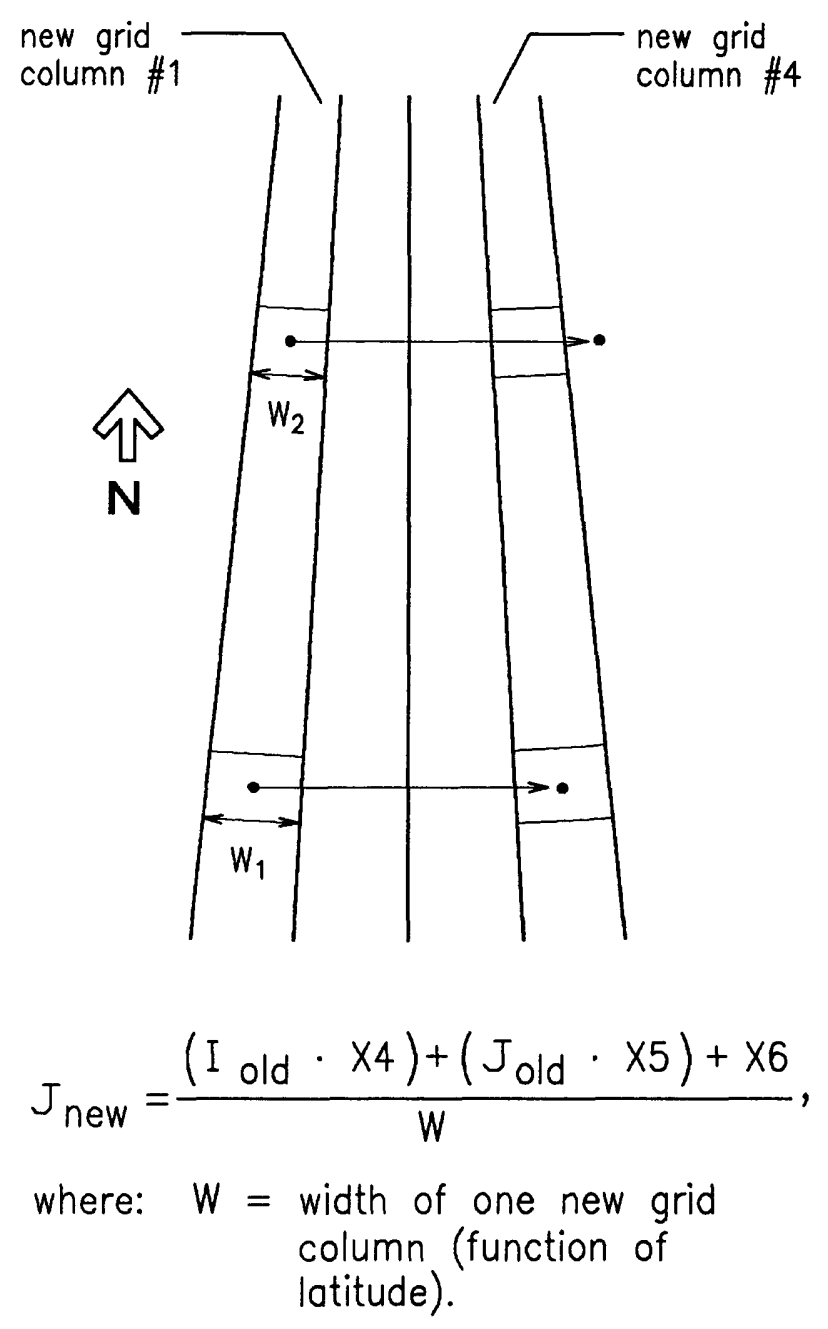

To derive expression for $W$ :

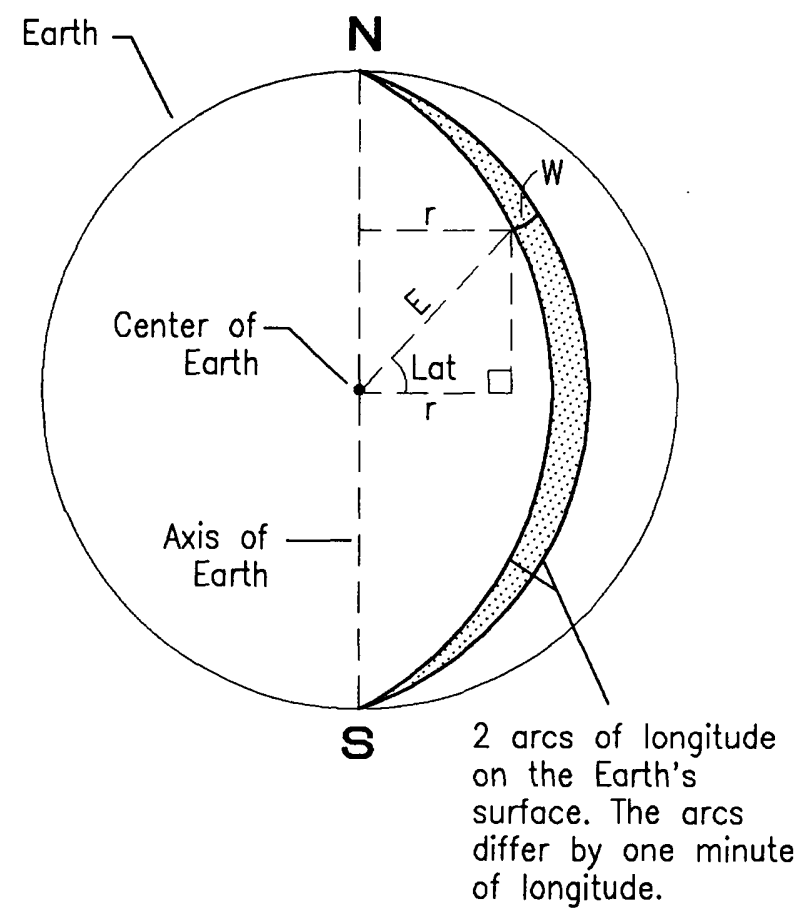

$r=$ distance to the axis of the Earth Lat $=$ latitude

$E=$ radius of the Earth

$$
\begin{gathered}
W=\frac{2 r \pi}{360 \cdot 60} \text { and } r=E \cdot \operatorname{Cos}(\text { Lat), so } \\
W=\frac{2 E \pi}{360 \cdot 60} \cdot \operatorname{Cos}(\text { Lat). }
\end{gathered}
$$

The term $\frac{2 E \pi}{360 \cdot 60}$ is constant, so it may be deleted from the equation for $J_{\text {new }}$ before solving for $X 4, X 5$, and $X 6$ :

$$
J_{\text {new }}=\frac{\left(I_{\text {old }} \cdot X 4\right)+\left(J_{\text {old }} \cdot X 5\right)+X 6}{\operatorname{Cos}(\text { Lat })},
$$

where Lat $=\left(I_{\text {old }} \cdot X 1\right)+\left(J_{\text {old }} \cdot X 2\right)+X 3$, approximately.

Figure 2.--Adjustments necessary for calculating new grid column number. 


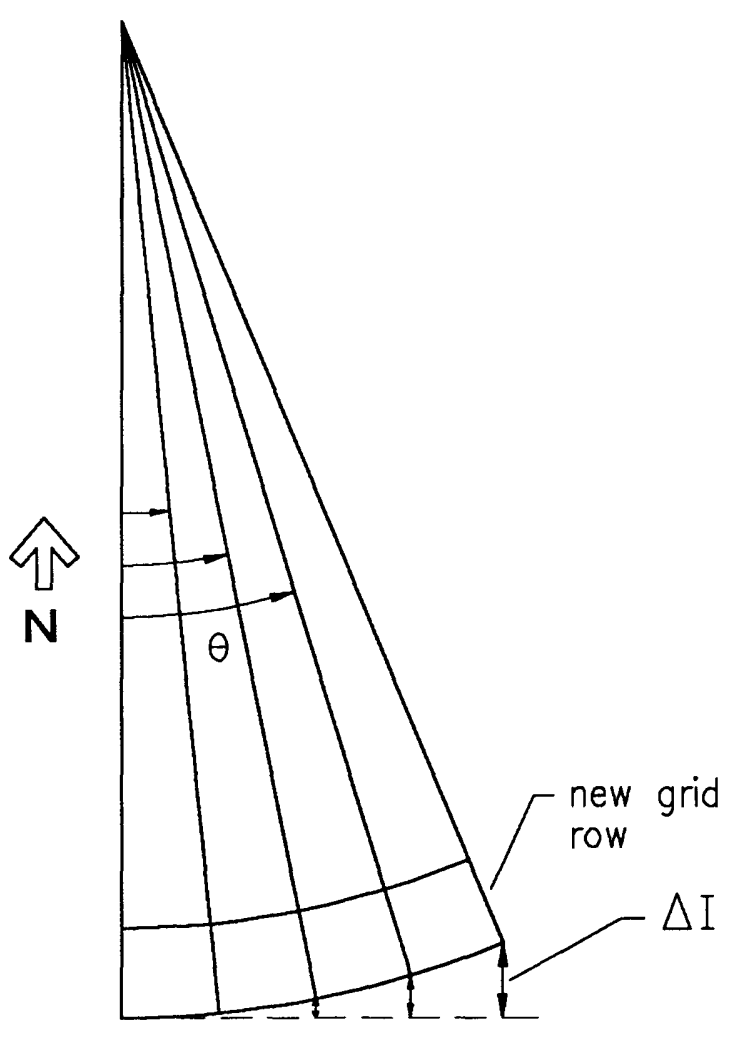

$I_{\text {new }}=\left(I_{\text {old }} \cdot X 7\right)+\left(J_{\text {old }} \cdot X 8\right)+X 9+\Delta I$,

where $\Delta \mathrm{I}=$ upward displacement of a new grid row with respect to the old (rectangular) grid. $\Delta I$ is a function of longitude (or new grid column number).
To derive an expression for $\Delta \mathrm{I}$ :

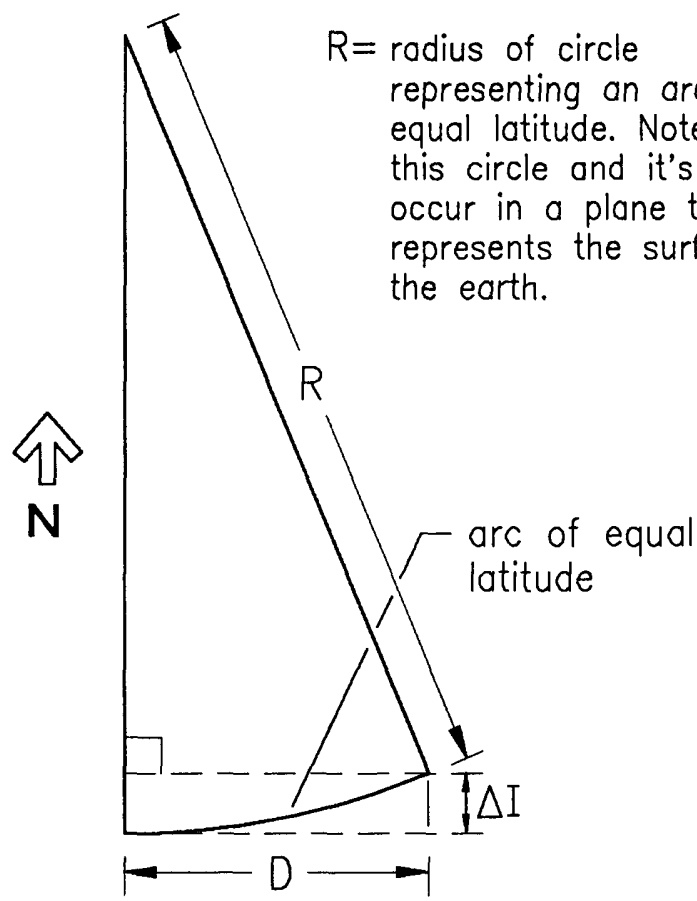

From the Pythagorean Theorom,

$$
\Delta I=R-\sqrt{R^{2}-D^{2}} .
$$

To express $D$ in the same units as $\Delta I$ (minutes of latitude),

$$
\begin{gathered}
D=J_{\text {new }} \cdot \operatorname{Cos}(\text { Lat }), \text { so } \\
\Delta I=R-\sqrt{R^{2}-\left(J_{\text {new }} \cdot \operatorname{Cos}(\text { Lat })\right)^{2}},
\end{gathered}
$$

and $R$ is expressed in minutes of latitude.

Figure 3.--Adjustments necessary for calculating new grid row number. 


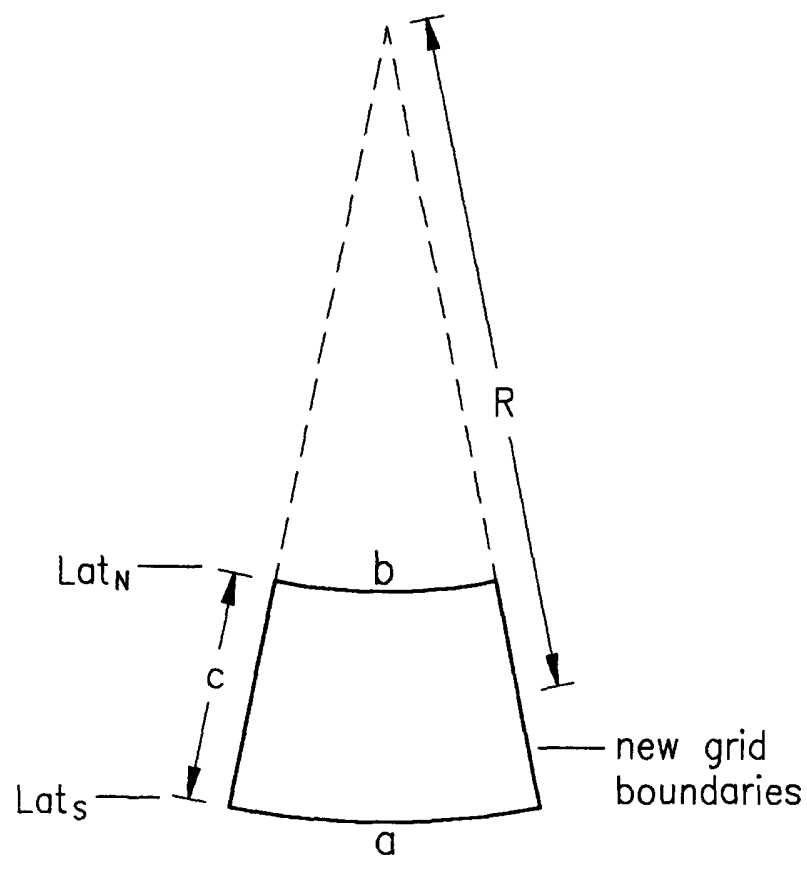

$R=$ average radius of circle representing an arç of equal latitude.

$$
\begin{aligned}
\frac{R-\frac{c}{2}}{b} & =\frac{R+\frac{c}{2}}{a} \\
a R-\frac{a c}{2} & =b R+\frac{b c}{2} \\
R(a-b) & =\frac{c}{2}(a+b) \\
R & =\frac{c}{2} \frac{(a+b)}{(a-b)} .
\end{aligned}
$$

Lat $_{N}$ and Lats are latitudes of northern and southern boundaries, in degrees, and Long $_{E}$ and Long $w$ are eastern and western boundaries, in degrees.

To express $a$ and $b$ in units of length, consider figure 2 :

$$
\begin{aligned}
& a=\frac{\left(\text { Long }_{W}-\text { Long }_{E}\right)}{360} 2 \pi E \operatorname{Cos}\left(\text { Lat }_{S}\right) \text {, } \\
& b=\frac{\left(\text { Long }_{W}-\text { Long }_{E}\right)}{360} 2 \pi E \operatorname{Cos}\left(\text { Lat }_{N}\right) \text {. } \\
& \text { Therefore: } \quad \frac{a+b}{a-b}=\frac{\operatorname{Cos}\left(\text { Lat }_{S}\right)+\operatorname{Cos}\left(\text { Lat }_{N}\right)}{\operatorname{Cos}\left(\text { Lat }_{S}\right)-\operatorname{Cos}\left(\text { Lat }_{N}\right)} \text {, dimensionless, }
\end{aligned}
$$

and, expressing $R$ and $C$ in minutes of latitude:

$$
\begin{aligned}
& R=\frac{c}{2} \frac{(a+b)}{(a-b)}=\frac{60\left(\operatorname{Lat}_{N}-\operatorname{Lat}_{S}\right)}{2}\left[\frac{\operatorname{Cos}\left(\operatorname{Lat}_{S}\right)+\operatorname{Cos}\left(\operatorname{Lat}_{N}\right)}{\operatorname{Cos}\left(\operatorname{Lat}_{S}\right)-\operatorname{Cos}\left(\operatorname{Lat}_{N}\right)}\right] \text {, or } \\
& R=30\left(\text { Lat }_{N}-\operatorname{Lat}_{S}\right)\left[\frac{\operatorname{Cos}\left(\operatorname{Lat}_{S}\right)+\operatorname{Cos}\left(\operatorname{Lat}_{N}\right)}{\operatorname{Cos}\left(\operatorname{Lat}_{S}\right)-\operatorname{Cos}\left(\operatorname{Lat}_{N}\right)}\right] .
\end{aligned}
$$

Figure 4.--Derivation of equation for $R$. 


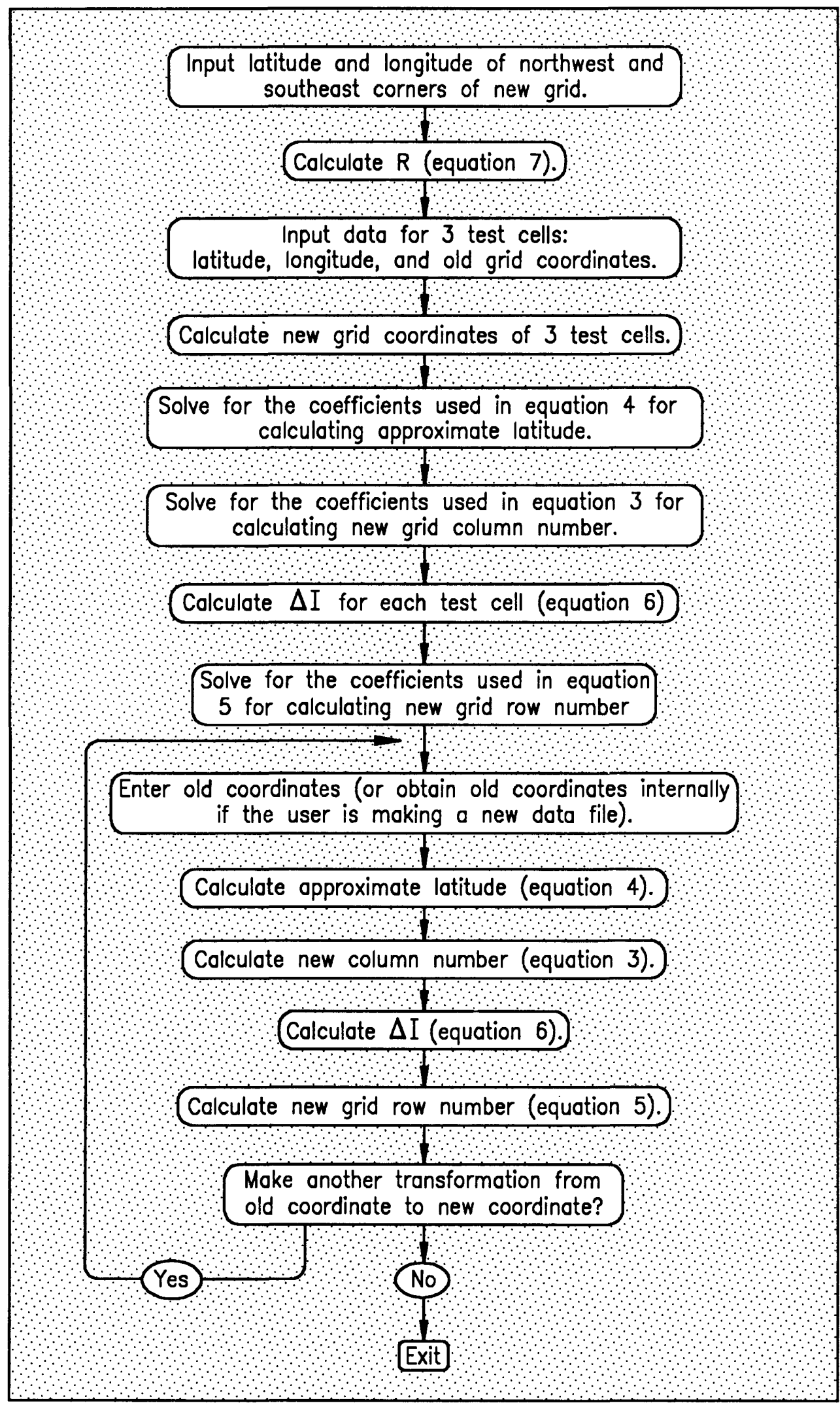

Figure 5.--Flow chart of procedures used by the program. 
coordinates. The only cells in the file "NEWDATA" that are given nonzero values are those that correspond to midpoints of the old grid cells that have nonzero values. It is left to the user to develop methods (interpolation, weighted averaging, and so forth) for assigning values to other cells based on needs associated with a particular modeling effort. Methods for this purpose were developed by Luckey and Ferrigno (1982).

A listing of the Fortran-77 code of program "GRID" is in the back of this report. Modification may be necessary to allow the user to vary the format of the data files "OLD DATA" and "NEW-

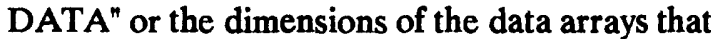

are stored on these files ("DATA1" on "OLDDATA" and "DATA2" on "NEWDATA"). Lines that may need modification are indicated with an asterisk on the right.

\section{SELECTED REFERENCE}

Luckey, R.R. and Ferrigno, C.R., 1982, A data-management system for areal interpretive data for the high plains in parts of Colorado, Kansas, Nebraska, New Mexico, Oklahoma, South Dakota, Texas, and Wyoming: U.S. Geological Survey WaterResources Investigations Report 82-4072, 112 pages. 
APPENDIX

page 11 followis 


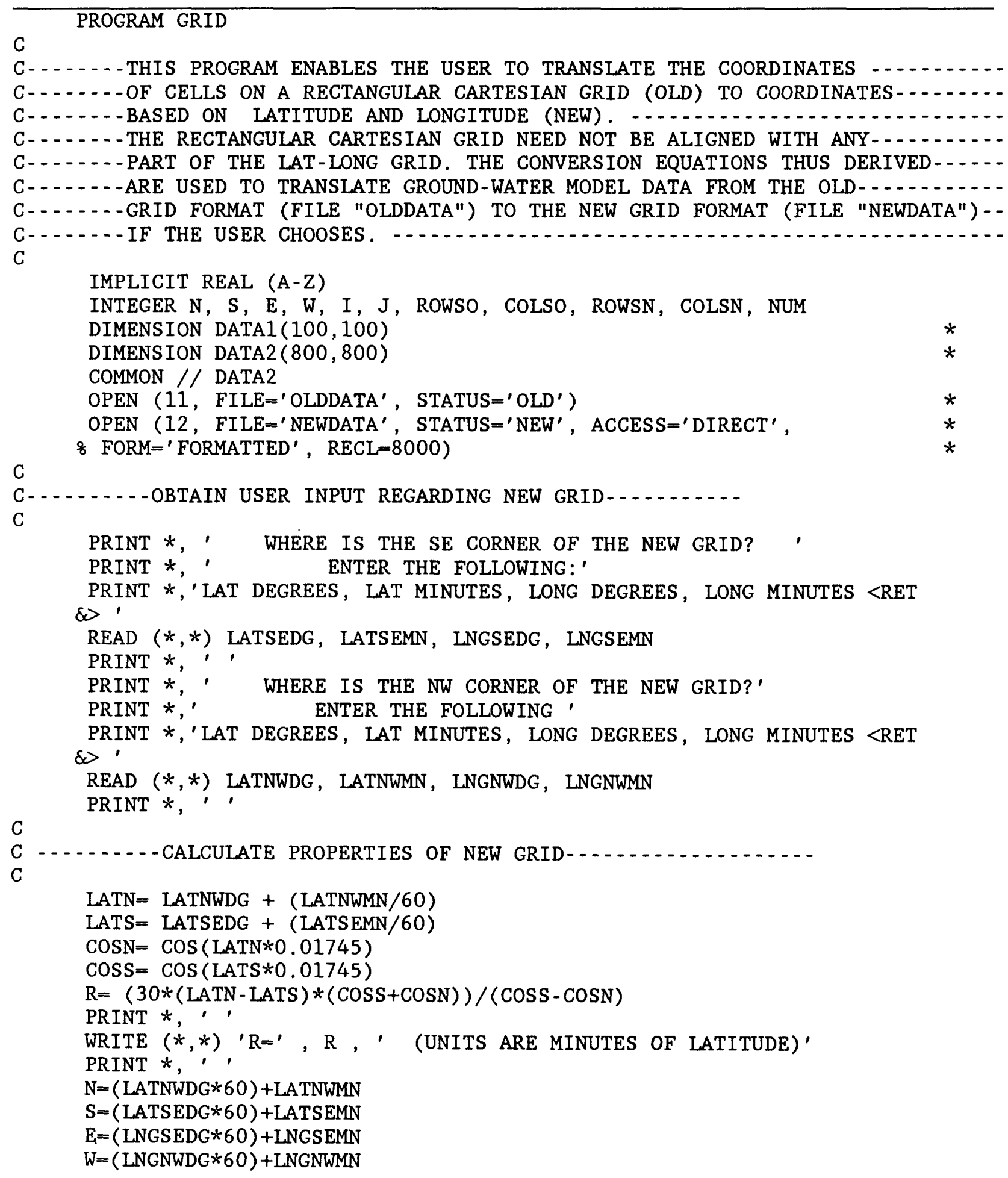




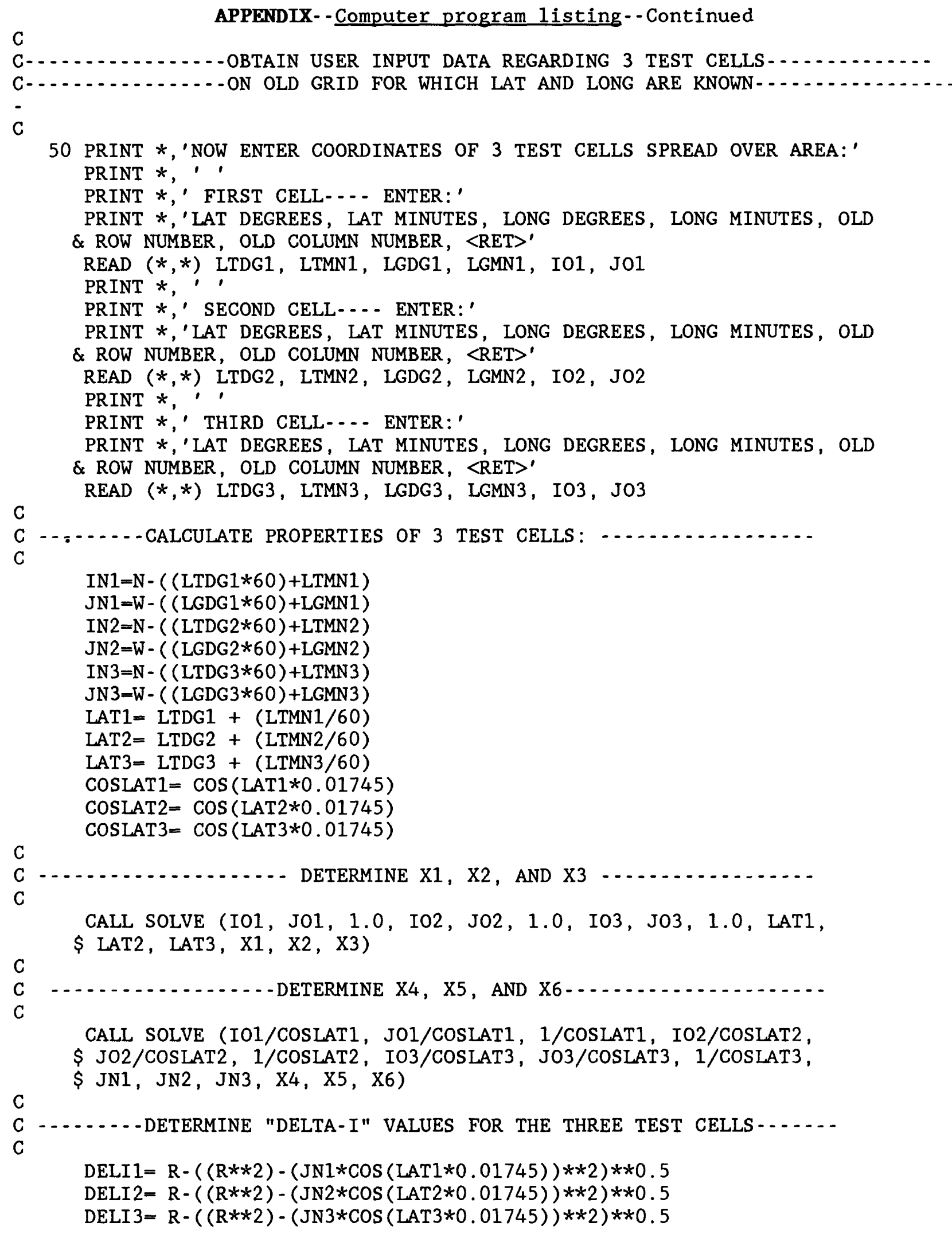




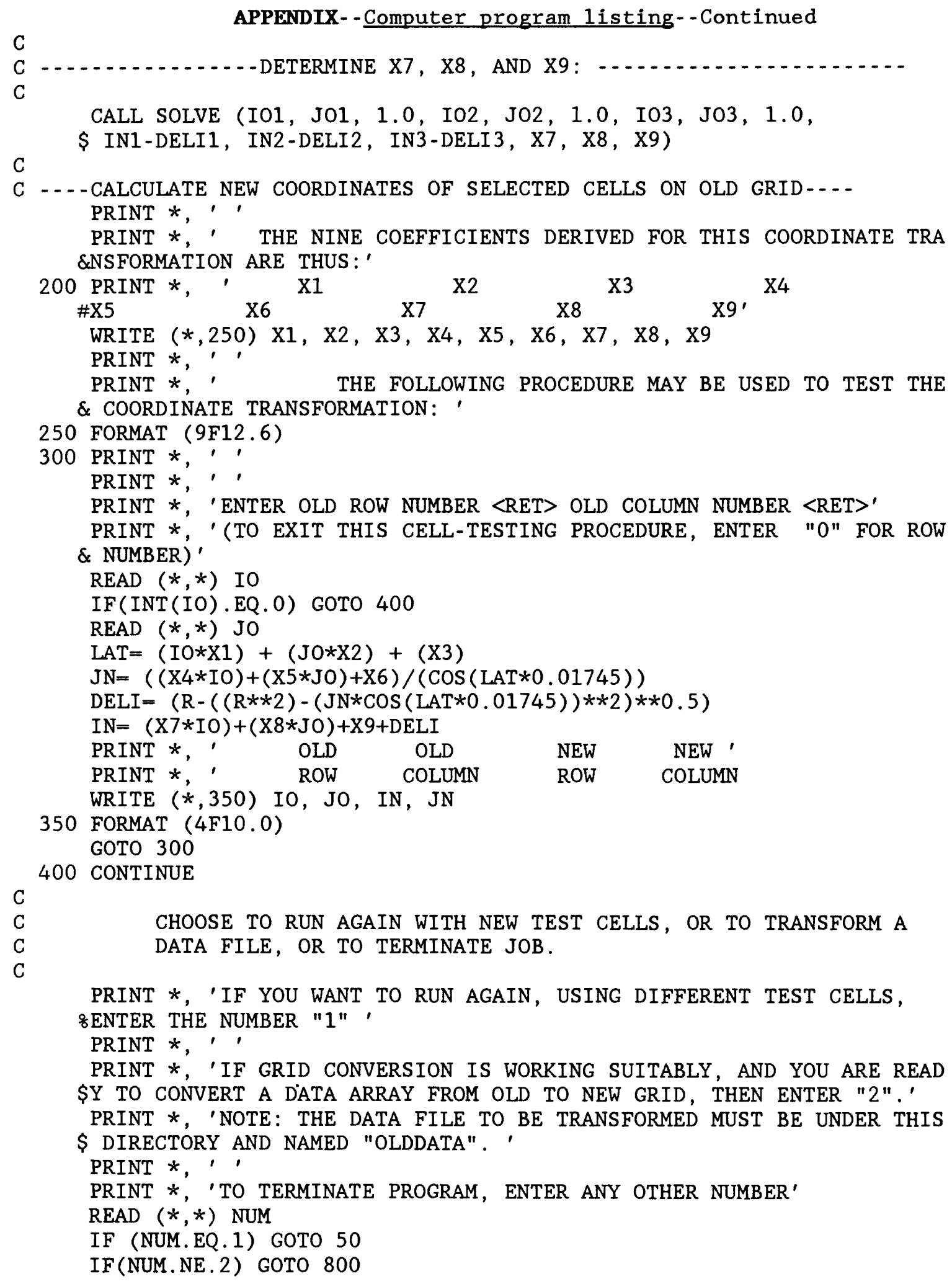




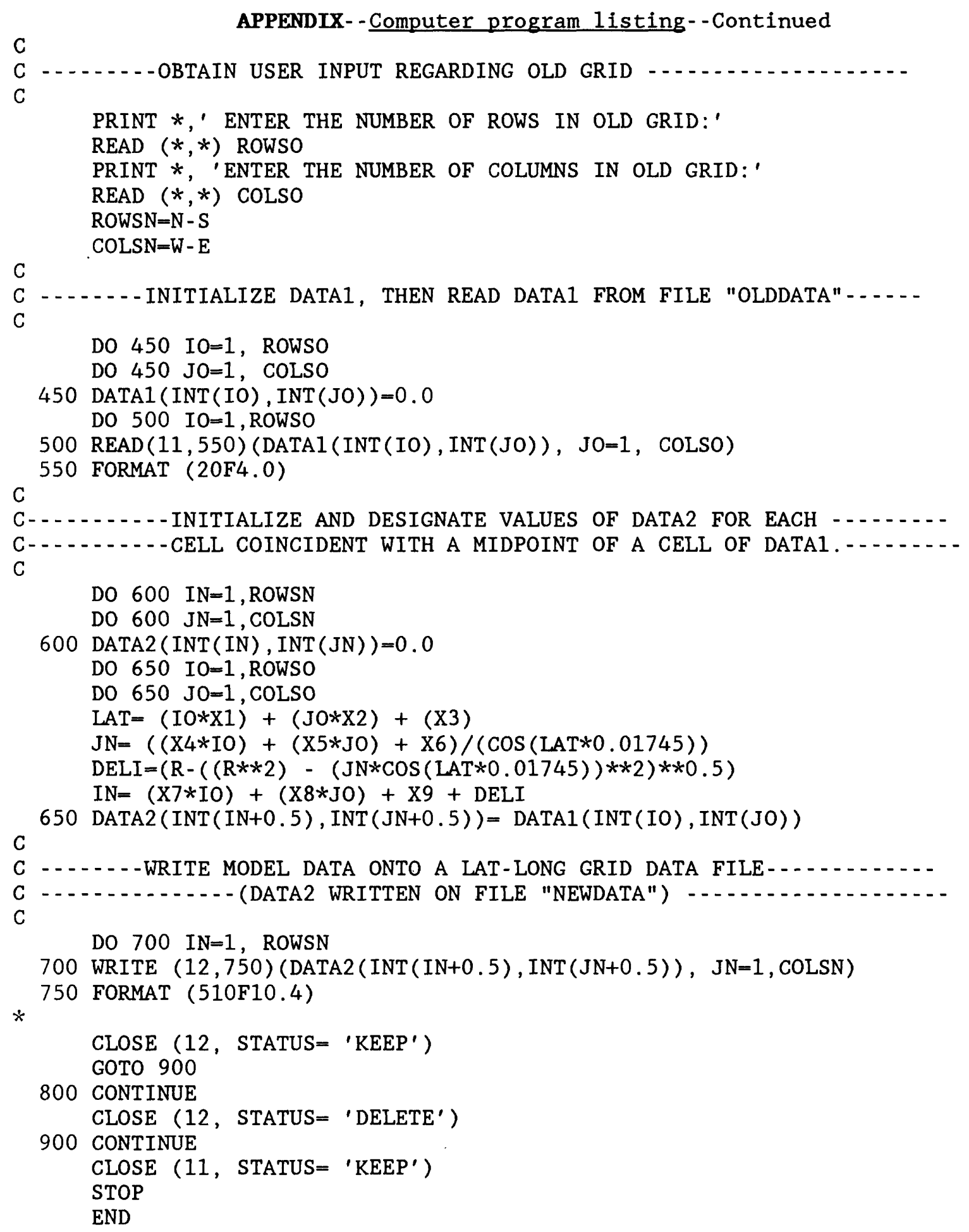




\section{APPENDIX--Computer program listing--Continued}

C

C

C

C

C

C

C

C

15

DO $40 \mathrm{I}=1,2$

$P=I$

$\operatorname{MX}=\mathrm{MAT}(I, I)$

DO $15 \mathrm{~K}=\mathrm{I}, 2$

IF (ABS (MX) . IT .ABS (MAT $(K+1, I))$ ) THEN $\mathrm{P}=1+\mathrm{K}$

$\mathrm{MX}=\mathrm{MAT}(K+1, I)$

END IF

CONTINUE

IF (P.NE.I) THEN

DO $18 \mathrm{~K}=1,4$

TEMP $=$ MAT $(I, K)$

$\operatorname{MAT}(I, K)=\operatorname{MAT}(P, K)$

18

END IF

19 DO $30 \mathrm{~J}=\mathrm{I}+1,3$

$$
M(J, I)=(\operatorname{MAT}(J, I)) /(\operatorname{MAT}(I, I))
$$

20

30 CONTINUE

40 CONTINUE

$$
\text { DO } 20 \mathrm{~K}=1,4
$$$$
\operatorname{MAT}(J, K)=\operatorname{MAT}(J, K)-(M(J, I) * \operatorname{MAT}(I, K))
$$

C 


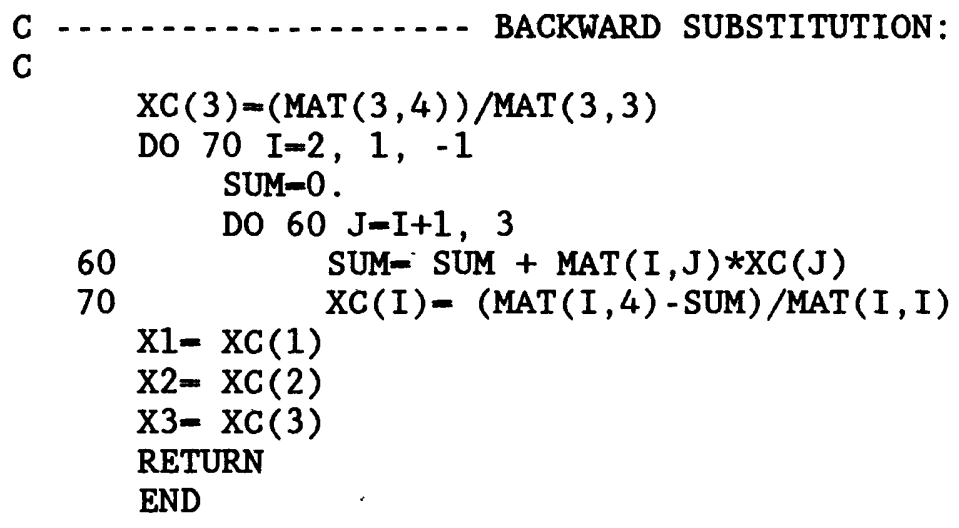

